\title{
EFFICINCY OF THREE BREEDING METHODS ON TWO BREAD WHEAT CROSSES \\ El-Hosary, A. A. ${ }^{1}$; S. A. Shafshak ${ }^{1}$; M. A. ABO-Sherif ${ }^{2}$; A. A. EL-Hosary ${ }^{1}$ and S. T. E. El-Sherif ${ }^{2}$ \\ 1-Agronomy Department, Faculty of Agriculture, Benha University. \\ 2-Wheat Research Department, Field Crops Research Institute, A. R. C.
}

\begin{abstract}
This study was conducted at the Experimental Farm of the Sids Agricultural Research Station, Agricultural Research Center, Egypt, during 2007/2008, 2008/2009 and 2009/2010 seasons. The objective of this study was; to estimate the efficiency of pedigree, modified bulk and single seed descent methods in two bread wheat populations. The final evaluation of the $F_{5}$ generation was done during 2009/2010 season. The selected lines were sown in the nested design with three replications. The efficiency of the breeding methods was evaluated on the basis of the following parameters: mean performance results in the first cross indicated that, the differences between breeding methods. The pedigree method expressed significant desirable values for number of spikes per plant, 1000-kernel weight, number of kernels/spike and grain yield/plant than those bulk and SSD method. The pedigree method produced consistently more superior lines for grain yield/plant compared to the best parent and the two checks (Sids1 \& Sids12)or the average. The best lines were number $16(45.80 \mathrm{~g})$, no. $14(43.22 \mathrm{~g})$ number $15(35.67 \mathrm{~g})$, no. $5(35.55 \mathrm{~g})$ and no. 13 ( $34.96 \mathrm{~g}$ ) in pedigree method and no. 6(39.52g) in bulk method. For number of Spikes/plant the results indicated the pedigree method produced more superior lines followed by bulk and then by SSD over lines with 2, 12,14 and 16; 14 and Zero lines, respectively. Regarding to 1000-kernel/weight, 2,3,5,8,10,13,18 and 19; 5; and 2 lines showed, significant overlines for pedigree, bulk and SSD methods, respectively. For number of kernels/spike, one line showed significant high .The lines number 1, 16, and 17 in pedigree breeding method and the line number 1 and 10 in bulk method gave the highest number of kernels/spike. The mean squares for breeding methods in the second cross were significant for yield and its components. The pedigree method gave the highest values for grain yield/plant, number of spikes per plant and number of kernels per spike. While the bulk method gave the highest value for 1000-kernel weight. While, SSD method exhibited significantly higher for1000-Kernel weight and number of kernels per spike. The pedigree method produced consistently more superior lines compared to the best parent and two cheeks (Sids1 \& Sids12)or the average population with no. 7 , no. 8 , no. 12 , no.13 and no.16; no.3, no.5, no.10 and no.15; no. 9 and no.20 for pedigree, bulk and SSD, respectively. The best lines were number 7 (38.30g), no.8 (48.23g) ,no. 12(40.50g),no.13(37.48g) and number 16 $(40.71 \mathrm{~g})$ in pedigree method.
\end{abstract}

\section{INTRODUCTION}

Wheat is one of the major cereal crops in Egypt, which receives the most attention of specialists in plant breeding. To increase grain yield per unit area which is, in most cases, the main or the only solution for overcoming the increasing demand of food from a limited cultivated area, plant breeders would develop high yielding wheat cultivars. Plant breeders are seeking 
continuously for more effective and efficient selection procedure. Numerous methods have been proposed, but only a few valid comparisons have been made among these procedures. Also, plant breeders are continually faced with the problem of how to evaluate available breeding materials (Atkins, 1953). For maximizing efficiency of selection, selection should be started as early as possible, and it's preferable in the $F_{2}$ generation (Knott and Kumar, 1975). The pedigree method proved to be most efficient and better method in selection for number of kernels per spike (Verma, et al., 1997) and for 1000kernel weight (Ismail, 1995, Ronga, et al., 1995 and Verma, et al., 1997). The pedigree selection was the best method for selecting number of spikes per plant, number of kernels per spike, 100-grain weight and grain yield per plant (Pawar et al. 1986). The modified bulk method proved to be most efficient and better method in selection for 1000-kernel weight (El-Shamy, 1987). For grain yield (Salmeron, 1985) and Malysh and Fomenko, 1988)., The single seed descent method proved to be most efficient and better method in selection 1000-kernel weight (Pawar, et al., 1989) and for grain yield per plant (Srivastava, et al., 1989, Snap et al., 1992 and Pawar, et al., 2001 ). The single seed descent was considered to be better than bulk selection. Pawar et al. (1985), The pedigree and SSD method were equally efficient, but the bulk method turned out to be less efficient.( Arunachalam et al. 2002). Successful breeding programs need enough information in breeding methods of selection. The objective of this study was to estimate of efficiency of three breeding methods in two bread wheat populations for three generations by the most economic traits of wheat i. e., , number of spikes per plant, number of kernels per spike, 1000 -kernel weight and grain yield per plant at the sids Agricultural Research Station .

\section{MATERIALS AND METHODS}

This study was carried out during the three successive seasons, i. e., 2007/2008, 2008/2009 and 2009/2010, at the Sids Agricultural Research Station conditions, Agricultural Research Center, Egypt. The present study aimed to measuring the efficiency of three methods of selection used in the wheat breeding program namely; pedigree method (PM), modified bulk method (MBM) and single seed descent method (SSDM)). In two hexaploid bread wheat (Triticum aestivum vulgare., L.) populations $(2 \mathrm{n}=42$ chromosomes) chosen from breeding wheat program at the Sids Station. The pedigree of the parents of the two wheat populations are given in (Table 1).In 2006/2007 season, about 1600 grains of bread wheat from each $F_{1}$ population were planted. Selection was practiced twice in season, at heading and at maturity stages, on the bases of high yield and yield components in addition to earliness and shortness. In the pedigree method, each selected plant was sown in a separate row as $\mathrm{F}_{3}$ families during 2007/2008 season. Selection between and within families was practiced. 40 families were selected from $160 F_{3}$ families to raise $F_{4}$ families in 2008/2009 season for each population. 20 families were selected from $F_{4}$ generation for each 
population and retained to be raise as $\mathrm{F}_{5}$ generation in the final evaluation trial during 2009/2010 season.

Table (1): The pedigree of the parents of the two wheat populations.

\begin{tabular}{|l|l|}
\hline \multicolumn{1}{|c|}{ Parental name } & \multicolumn{1}{c|}{ Pedigree } \\
\hline Population I & \\
$\left(P_{1}\right)$ Line & FLORKA-2 / Kauz "s" \\
$\left(P_{2}\right)$ Sakha93 & Sakha92 / TR810328 \\
\hline $\begin{array}{l}\text { Population II } \\
\left(P_{1}\right) \text { Line }\end{array}$ & KAUZ//ALTAR84/AOS/3/KAUZ \\
$\left(P_{2}\right)$ Sids6 & Maya "S " / Mon "S " // CMH 74 A. 592 /3/ Sakha8*2. \\
\hline
\end{tabular}

In the modified bulk method, few grains from each selected plant from each $\mathrm{F}_{2}$ population were mixed to form the population grain bulk. The mixed grains were planted during 2007/2008 growing season as $F_{3}$ generations. Selection was practiced on the basis of best plants per each population. Grains of the selected plants were mixed to form grains bulk and grains sample was taken to be raised as $\mathrm{F}_{4}$ generations during the growing season of 2008/2009. Similarly, 20 plants per population were selected and were harvested individually. Grains from each plant were kept and were planted separately as $F_{5}$ populations during 2009/2010 growing season.

In the single seed descent method, one grain was taken from 500 plant from $F_{2}$ population and planted during 2007/2008 season as $F_{3}$ generations. One grain was taken from each plant to be grown as $F_{4}$ generations during the growing season of 2008/2009. Similarly, 20 plants were selected from each population and were harvested individually. Grains from each plant were kept and planted separately as $F_{5}$ plants during 2009/2010 season.

In 2010 season, the high yielding selected lines (20) from each method of breeding (three methods i.e. pedigree, bulk and SSD) and the two parents and two check cultivars (Sids1\&sids12) were represented by one row per plot, a row was three meters in length, $20 \mathrm{~cm}$. between rows and $10 \mathrm{~cm}$. between grains were evaluated in nested design with three replications in each cross

Sowing date was: 17 November. in the $1^{\text {st }}$ season $\left(F_{3}\right.$ generation 2008), 22 November in the $2^{\text {nd }}$ season $(2009) ; 12$ December. in the $3^{\text {rd }}$ season (2010)

The following characteristics were measured on random sample of 10 guarded plants in each plot for each in $F_{3}$ and $F_{4}$ and each line in $F_{5}$ generation. The mean of the 10 plants were subjected to the statistical and genetic analysis for:

1- Number of spikes per plant [S/P].

2- Number of kernels per spike [K/S]:- Average number of kernels per main spike of the plant.

3- 1000-kernel weight $[1000-\mathrm{KW}]$ in $\mathrm{g}$.

4- Grain yield per plant [GY/P] in $g$ :- It was recorded as the weight of individual plant grains. 


\section{RESULTS AND DESCUSSION}

\section{First cross}

$F_{5}$ generation:

Mean squares due to breeding methods were significant for yield and its components (Table 2). This result indicated the differences between breeding methods.

The pedigree method expressed significant desirable values for number of spikes per plant, 1000-kernel weight and grain yield/plant (Table 3 ). It could be concluded that pedigree method considered the best breeding method for number of spikes per plant, 1000-kernel weight, and grain yield/plant than those of bulk and SSD methods in this cross.

Working on self pollination crops, breeders applied one or more different breeding methods in order to investigate or compare their efficiency in selecting high Grain yield. Among those, Schutz et al. (1968), Allard and Adams (1969),. on barley and wheat using two or more methods of breeding.

Whan et al. (1982) found that the effect of selection using the means of lines from the $F_{3}$ and $F_{4}$ rather than the individual $F_{2}$ or $F_{3}$ derived lines, can be assessed by the yields obtained in the following generations. The improvement obtained in the $F_{5}$ by selecting $F_{2}$ derived lines was much greater in the second cross. When selection is carried out in an early generation e.g. among $F_{2}$ derived lines, the important consideration is the response to this selection in a late generation e.g. the $F_{5}$ when lines are approaching homozygosis. In the simulated schemes considered here, the available data enabled each selected line to be continued with one random line only. This caused a less of variation for yield and the gain from selection was often reduced in the generations following selection.

Mean squares due to lines of breeding methods as well as two parents and two checks (Sids1\& Sids12) were significant for the four traits under study (Table 2). Also, the efficiency of the breeding methods in the present study was evaluated based on the number of superior lines having higher values of grain yield/plant than the best parent and two checks (Sids1 \& Sids12)

Data presented in Table (6) show that the pedigree method produced consistently more superior lines for grain yield /plant compared to the best parent and the two cheeks (Sids1 \& Sids12)or the average population with no. 2 , no. , no. 4 , no.5, no.6, no.8, no.13, no.14, no.15, no.16, no.17 and no.19; no.3, no.6, no.9 and no.10; no. 7 for pedigree, bulk and SSD, respectively. The best lines were number $16(45.80 \mathrm{~g})$ and no. $14(43.22 \mathrm{~g})$ in pedigree method, no. $6(39.52 \mathrm{~g})$ in bulk method and number $15(35.67 \mathrm{~g})$, no. $5(35.55 \mathrm{~g})$ and no. $13(34.96 \mathrm{~g})$ in pedigree method.

For number of Spikes/plant the results indicated that the pedigree method produced more superior lines followed by bulk and then by SSD compared to the best parent and the two cheeks (Sids1 \& Sids12) or average over lines with 14; 9; Zero lines, respectively.

Regarding to 1000 -kernels/weight, 2,3,5,8,10,13,19; 5; 2 lines showed, significant higher than the best parent and the two cheeks (Sids1 \& 
Sids12) and average over lines for pedigree, bulk and SSD methods, respectively. The heavier line was number $10(71.70 \mathrm{~g})$ followed by line number $13(68.52 \mathrm{~g})$ and then by line number $19(68.34 \mathrm{~g})$ in pedigree method and number $5(69.53 \mathrm{~g})$ in bulk method and number 2 (68.95g)in SSD method (Table 6).

For number of kernels/spike, one line showed significant higher For number of kernels/spike than the average of all lines or best parent and two cheeks (Sids1 \& Sids12). The line number 1, 16, and 17 in pedigree breeding method and the line number 1 and 10 in bulk method gave the highest number of kernels/spike.

Results of the present study indicate that visual selection for yield by pedigree method or early generation testing in wheat can lead to lines with increased yield.

The pedigree method seemed to be an effective than two other methods. Based on the combining ability studies, successfully applied early generation selection procedure for yield improvement in wheat. Accordingly, Casali and Tigchelaar (1975) compared PS, SSD and bulk breeding methods in self-pollinated populations by computer simulation.

Table (2): Mean squares of the breeding methods of the $F_{5}$ lines for the four traits studied in the first cross

\begin{tabular}{|l|c|c|c|c|c|}
\hline $\begin{array}{c}\text { Source of } \\
\text { variation }\end{array}$ & $\begin{array}{c}\text { Degrees of } \\
\text { freedom }\end{array}$ & $\begin{array}{c}\text { No. of } \\
\text { spikes/plant }\end{array}$ & $\begin{array}{c}\text { 1000- kernel } \\
\text { weight }(\mathbf{g})\end{array}$ & $\begin{array}{c}\text { No. of } \\
\text { kernels/spike }\end{array}$ & $\begin{array}{c}\text { Grain } \\
\text { yield/plant (g) }\end{array}$ \\
\hline Replications & 2 & $15.26^{\star *}$ & 18.81 & 12.83 & 9.36 \\
\hline Lines (L) & 59 & $10.02^{* *}$ & $156.02^{* *}$ & $232.28^{\star *}$ & $123.30^{* *}$ \\
\hline Methods(M) & 2 & $29.42^{* *}$ & $1897.20^{\star *}$ & 50.25 & $1298.66^{\star *}$ \\
\hline L/M & 57 & $9.34^{\star *}$ & $94.93^{\star *}$ & $238.67^{\star *}$ & $82.05^{\star *}$ \\
\hline Error & 118 & 1.959 & 19.467 & 41.80 & 9.77 \\
\hline
\end{tabular}

*, ** Significant and highly significant at 0.05 and 0.01 respectively.

Table (3): Mean performance of the breeding methods of the $F_{5}$ lines for the four traits studied in the first cross

\begin{tabular}{|l|c|c|c|c|}
\hline $\begin{array}{c}\text { Breeding } \\
\text { methodology }\end{array}$ & $\begin{array}{c}\text { No. of } \\
\text { spikes/plant }\end{array}$ & $\begin{array}{c}\text { 1000- kernel } \\
\text { weight } \mathbf{( g )}\end{array}$ & $\begin{array}{c}\text { No. of } \\
\text { kernels/spike }\end{array}$ & $\begin{array}{c}\text { Grain } \\
\text { yield/plant (g) }\end{array}$ \\
\hline Pedigree & 10.76 & 62.29 & 65.39 & 32.77 \\
\hline Bulk & 9.58 & 52.42 & 64.39 & 26.20 \\
\hline Single seed & 9.52 & 52.69 & 63.56 & 23.78 \\
\hline L.S.D $5 \%$ & 0.51 & 1.59 & 2.34 & 1.13 \\
\hline L.S.D $1 \%$ & 0.67 & 2.11 & 3.09 & 1.49 \\
\hline
\end{tabular}

\section{Second cross}

$F_{5}$ generation

The mean squares for breeding methods were significant for yield and its components (Table 4). These results indicated the differences between breeding methods.

The pedigree method gave the highest values for grain yield/plant, number of spikes per plant and number of kernels per spike. While the Bulk method gave the highest values for 1000-kernel weight. While, SSD method exhibited significantly higher for1000-Kernel weight and number of kernels 
per spike (Table 5). It could be concluded that pedigree method considered the best breeding method for grain yield/plant, number of spikes per plant and number of kernels per spike and the third for 1000-Kernel weight, than those pedigree and SSD in this cross.

Mean squares due to lines of breeding methods as well as two parents and two cheeks (Sids1 \& Sids12) were significant for the four traits under study. Also,the efficiency of the breeding methods in the present study was evaluated based on the number of superior lines having higher values of grain yield/plant than the best parent and the two cheeks (Sids1 \& Sids12)

Table (4): Mean squares of the breeding methods of the $F_{5}$ lines for the four traits studies in the second cross

\begin{tabular}{|l|c|c|c|c|c|}
\hline $\begin{array}{c}\text { Source of } \\
\text { variation }\end{array}$ & $\begin{array}{c}\text { Degrees of } \\
\text { freedom }\end{array}$ & $\begin{array}{c}\text { No. of } \\
\text { spikes/plant }\end{array}$ & $\begin{array}{c}\text { 1000- kernel } \\
\text { weight }(\mathbf{g})\end{array}$ & $\begin{array}{c}\text { No. of } \\
\text { kernel/spike }\end{array}$ & $\begin{array}{c}\text { Grain } \\
\text { yield/plant (g) }\end{array}$ \\
\hline Replications & 2 & $3.69^{*}$ & 35.21 & 67.48 & 9.10 \\
\hline Lines (L) & 59 & $8.51^{\star *}$ & $62.10^{\star *}$ & $329.98^{\star *}$ & $110.95^{\star *}$ \\
\hline Methods(M) & 2 & $29.72^{\star *}$ & $706.02^{\star *}$ & $2146.20^{\star *}$ & $807.75^{\star *}$ \\
\hline L/M & 57 & $7.77^{\star *}$ & $39.51^{\star *}$ & $266.26^{*}$ & $86.50^{\star *}$ \\
\hline Error & 118 & 0.98 & 17.41 & 55.41 & 15.25 \\
\hline
\end{tabular}

*, ** Significant and highly significant at 0.05 and 0.01 respectively.

Data presented in Table(6) show that the pedigree method produced consistently more superior lines compared to the best parent and two checks (Sids1 \& Sids12)or the average population with no. 7 , no.8, no. 12, no.13 and no.16; no.3, no.5, no.10 and no.15; no. 9 and no.20 for pedigree, bulk and SSD, respectively. The best lines were number $7(38.30 \mathrm{~g})$,no. $8(48.23 \mathrm{~g})$,no. $12(40.50 \mathrm{~g}), \mathrm{no} .13(37.48 \mathrm{~g})$ and number $16(40.71 \mathrm{~g})$ in pedigree method

Table (5): Mean performances of the breeding methods in the $F_{5}$ lines for the four studied traits in the second cross

\begin{tabular}{|l|c|c|c|c|}
\hline \multicolumn{1}{|c|}{$\begin{array}{c}\text { Breeding } \\
\text { methodology }\end{array}$} & $\begin{array}{c}\text { No. of } \\
\text { spikes/plant }\end{array}$ & $\begin{array}{c}\text { 1000-kernel } \\
\text { weight } \mathbf{( g )}\end{array}$ & $\begin{array}{c}\text { No. of } \\
\text { kernel/spike }\end{array}$ & $\begin{array}{c}\text { Grain } \\
\text { yield/plant (g) }\end{array}$ \\
\hline Pedigree & 11.23 & 49.09 & 68.911 & 33.29 \\
\hline Bulk & 10.79 & 55.85 & 57.461 & 27.83 \\
\hline Single seed & 9.86 & 53.46 & 66.183 & 26.31 \\
\hline L.S.D $5 \%$ & 0.36 & 1.51 & 2.691 & 1.41 \\
\hline L.S.D $1 \%$ & 0.47 & 1.99 & 3.556 & 1.87 \\
\hline
\end{tabular}

For number of Spikes/plant the results indicated that the pedigree method produced more superior lines followed by bulk and then by SSD compared to the best parent and cheek (Sids12) or average over lines with 2, $3,11,13$ and 16;1,7,15 and 16; 9 lines, respectively.

Regarding to 1000 -kernel/weight, zero; 2,13,14 and 16 ; zero lines showed, significant higher than the best parent and two cheek (Sids1 \& Sids12) and average over lines for pedigree, bulk and SSD methods, respectively. The heavier line was number $13(62.88)$ followed by line number $1(62.76)$ and then by line number 14 (60.55)and line number 16(59.73) in bulk method (Table 6). 
For number of kernels/spike, four lines showed significant higher kernels number than the average of all lines or best parent and two cheeks (Sids1 \& Sids12) in pedigree breeding method and SSD breeding method. The line number 2 and 12 in pedigree breeding method and the lines number 2,4 and 7 in SSD method gave the highest number of kernels/spike.

Table (6): Mean performance of the selected lines of breeding methods and two parents and check varieties in the first cross population.

\begin{tabular}{|c|c|c|c|c|c|c|c|c|c|}
\hline \multirow{2}{*}{$\begin{array}{l}\text { Breeding } \\
\text { Method }\end{array}$} & \multirow[b]{2}{*}{$\begin{array}{l}\text { N. } \\
\text { line }\end{array}$} & \multicolumn{4}{|c|}{ POPULATION 1} & \multicolumn{4}{|c|}{ POPULATION2 } \\
\hline & & N.S/P & $\begin{array}{c}1000- \\
K . W(g)\end{array}$ & N.K/S & GY/p (g) & N.S/P & $\begin{array}{c}1000- \\
K . W(g)\end{array}$ & N.K/S & GY/P (g) \\
\hline \multirow{20}{*}{$\begin{array}{l}\text { ఖ } \\
\text { 흥 } \\
\text { 임 }\end{array}$} & 1 & 7 & 54.87 & 86 & 30.36 & 10 & 52.29 & 57 & 25.26 \\
\hline & 2 & 13 & 68.20 & 49 & 34.59 & 14 & 43.04 & 82 & 35.65 \\
\hline & 3 & 12 & 65.97 & 49 & 34.91 & 13 & 54.86 & 60 & 35.48 \\
\hline & 4 & 11 & 59.03 & 72 & 34.12 & 11 & 48.99 & 70 & 34.36 \\
\hline & 5 & 12 & 68.00 & 56 & 35.55 & 10 & 50.09 & 79 & 27.71 \\
\hline & 6 & 12 & 62.96 & 61 & 34.82 & 11 & 52.57 & 74 & 32.57 \\
\hline & 7 & 11 & 62.65 & 71 & 25.65 & 12 & 56.52 & 61 & 38.30 \\
\hline & 8 & 10 & 65.88 & 64 & 33.29 & 10 & 47.68 & 54 & 48.23 \\
\hline & 9 & 11 & 62.45 & 66 & 23.83 & 10 & 48.90 & 59 & 35.50 \\
\hline & 10 & 11 & 71.70 & 50 & 26.65 & 12 & 50.53 & 59 & 28.14 \\
\hline & 11 & 10 & 62.49 & 60 & 22.74 & 13 & 42.07 & 63 & 30.61 \\
\hline & 12 & 13 & 62.32 & 74 & 30.46 & 10 & 50.18 & 89 & 40.50 \\
\hline & 13 & 11 & 68.52 & 74 & 34.96 & 13 & 49.79 & 72 & 37.48 \\
\hline & 14 & 14 & 63.06 & 57 & 43.22 & 9 & 50.75 & 69 & 28.49 \\
\hline & 15 & 12 & 60.86 & 55 & 35.67 & 12 & 49.85 & 76 & 33.39 \\
\hline & 16 & 13 & 57.57 & 83 & 45.80 & 13 & 50.45 & 58 & 40.71 \\
\hline & 17 & 8 & 43.21 & 83 & 34.10 & 11 & 47.05 & 70 & 25.58 \\
\hline & 18 & 6 & 62.92 & 67 & 29.31 & 9 & 46.68 & 79 & 27.26 \\
\hline & 19 & 8 & 68.34 & 62 & 34.40 & 10 & 42.69 & 79 & 32.96 \\
\hline & 20 & 9 & 54.79 & 70 & 30.93 & 12 & 46.72 & 68 & 27.58 \\
\hline \multirow{20}{*}{ 产 } & 1 & 6 & 57.83 & 79 & 22.67 & 13 & 62.76 & 68 & 26.27 \\
\hline & 2 & 10 & 55.06 & 64 & 23.47 & 10 & 47.55 & 56 & 27.20 \\
\hline & 3 & 10 & 53.21 & 66 & 32.37 & 12 & 47.48 & 51 & 34.53 \\
\hline & 4 & 10 & 51.58 & 62 & 27.89 & 9 & 53.30 & 56 & 24.30 \\
\hline & 5 & 10 & 69.53 & 60 & 23.28 & 11 & 54.66 & 52 & 31.62 \\
\hline & 6 & 11 & 47.55 & 55 & 39.52 & 11 & 57.09 & 53 & 21.73 \\
\hline & 7 & 8 & 45.96 & 63 & 28.86 & 13 & 58.89 & 55 & 29.27 \\
\hline & 8 & 9 & 50.22 & 62 & 13.93 & 12 & 51.12 & 62 & 26.79 \\
\hline & 9 & 14 & 45.70 & 60 & 33.06 & 9 & 56.34 & 55 & 24.40 \\
\hline & 10 & 10 & 51.68 & 78 & 33.60 & 10 & 55.27 & 62 & 33.84 \\
\hline & 11 & 9 & 49.20 & 70 & 21.89 & 8 & 58.66 & 54 & 17.70 \\
\hline & 12 & 10 & 54.20 & 63 & 22.29 & 8 & 55.37 & 63 & 27.52 \\
\hline & 13 & 10 & 51.41 & 67 & 29.68 & 10 & 62.88 & 58 & 28.57 \\
\hline & 14 & 12 & 48.68 & 66 & 30.57 & 11 & 60.55 & 48 & 29.14 \\
\hline & 15 & 11 & 49.99 & 63 & 22.76 & 13 & 58.93 & 56 & 32.72 \\
\hline & 16 & 10 & 55.58 & 57 & 24.98 & 13 & 59.73 & 54 & 30.62 \\
\hline & 17 & 8 & 49.15 & 76 & 16.99 & 10 & 58.35 & 58 & 28.69 \\
\hline & 18 & 7 & 56.87 & 56 & 20.66 & 10 & 54.15 & 68 & 23.24 \\
\hline & 19 & 9 & 51.09 & 65 & 25.19 & 11 & 50.26 & 62 & 26.28 \\
\hline & 20 & 8 & 53.83 & 57 & 30.31 & 11 & 53.64 & 58 & 32.18 \\
\hline
\end{tabular}


El-Hosary, A. A. et al.

Table (6): Contact

\begin{tabular}{|c|c|c|c|c|c|c|c|c|c|}
\hline \multirow[b]{2}{*}{$\begin{array}{l}\text { Breeding } \\
\text { Method }\end{array}$} & \multirow[b]{2}{*}{ N. line } & \multicolumn{4}{|c|}{ POPULATION 1} & \multicolumn{4}{|c|}{ POPULATION2 } \\
\hline & & N.S/P & $\begin{array}{l}1000- \\
\text { K.W(g) }\end{array}$ & N.K/S & GY/P (g) & N.S/P & $\begin{array}{r}1000- \\
\text { K.W(g) }\end{array}$ & N.K/S & GY/P (g) \\
\hline \multirow{20}{*}{ 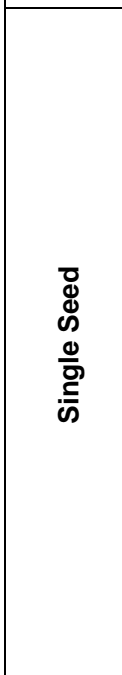 } & 1 & 8 & 52.82 & 75 & 23.75 & 7 & 55.16 & 76 & 27.41 \\
\hline & 2 & 8 & 68.95 & 71 & 20.53 & 10 & 51.02 & 86 & 31.60 \\
\hline & 3 & 12 & 52.41 & 70 & 25.20 & 10 & 56.77 & 57 & 29.12 \\
\hline & 4 & 7 & 50.03 & 67 & 21.71 & 10 & 53.55 & 81 & 29.98 \\
\hline & 5 & 11 & 48.14 & 64 & 25.41 & 8 & 55.07 & 71 & 17.70 \\
\hline & 6 & 9 & 57.37 & 54 & 21.21 & 8 & 52.16 & 70 & 21.44 \\
\hline & 7 & 8 & 52.49 & 70 & 32.78 & 12 & 52.51 & 84 & 25.91 \\
\hline & 8 & 8 & 52.02 & 67 & 18.86 & 7 & 55.93 & 59 & 24.79 \\
\hline & 9 & 10 & 54.57 & 74 & 27.17 & 14 & 55.79 & 48 & 36.10 \\
\hline & 10 & 11 & 53.53 & 74 & 22.78 & 8 & 51.06 & 55 & 19.00 \\
\hline & 11 & 9 & 52.30 & 55 & 23.57 & 8 & 53.87 & 75 & 18.57 \\
\hline & 12 & 10 & 48.19 & 53 & 22.55 & 12 & 55.03 & 50 & 31.98 \\
\hline & 13 & 9 & 53.09 & 53 & 21.73 & 10 & 53.04 & 55 & 24.65 \\
\hline & 14 & 10 & 46.50 & 71 & 20.26 & 11 & 55.69 & 74 & 30.77 \\
\hline & 15 & 8 & 42.23 & 56 & 21.17 & 10 & 54.99 & 69 & 26.90 \\
\hline & 16 & 10 & 56.02 & 58 & 23.97 & 11 & 51.42 & 70 & 31.61 \\
\hline & 17 & 10 & 51.98 & 68 & 29.81 & 12 & 49.26 & 72 & 15.98 \\
\hline & 18 & 12 & 54.87 & 64 & 20.88 & 10 & 53.66 & 45 & 21.70 \\
\hline & 19 & 11 & 54.73 & 60 & 27.31 & 8 & 47.97 & 62 & 27.03 \\
\hline & 20 & 10 & 51.53 & 50 & 24.89 & 10 & 55.32 & 64 & 33.95 \\
\hline \multicolumn{2}{|l|}{ Parent 1} & 10 & 53.21 & 58 & 23.30 & 10 & 51.94 & 69 & 27.88 \\
\hline \multicolumn{2}{|l|}{ Parent 2} & 10 & 56.89 & 74 & 28.47 & 8 & 51.25 & 62 & 25.58 \\
\hline \multicolumn{2}{|l|}{ Sids 1} & 12 & 54.29 & 66 & 23.27 & 13 & 53.01 & 66 & 30.04 \\
\hline \multicolumn{2}{|l|}{ Sids 12} & 8 & 51.65 & 67 & 26.28 & 11 & 51.23 & 64 & 28.63 \\
\hline \multicolumn{2}{|c|}{ Over mean } & 10 & 55.80 & 64 & 27.58 & 11 & 52.80 & 64 & 29.14 \\
\hline \multicolumn{2}{|l|}{ L.S.D $5 \%$} & 2 & 7.13 & 10 & 5.06 & 2 & 6.75 & 12 & 6.31 \\
\hline \multicolumn{2}{|l|}{ L.S.D } & 3 & 9.43 & 14 & 6.68 & 2 & 8.92 & 16 & 8.34 \\
\hline
\end{tabular}

Results of the present study indicate that visual selection for yield by pedigree method or early generation testing in wheat can lead to lines with increased yield.

The pedigree method seemed to be an effective than two other methods. Based on the combining ability studies, successfully applied early generation selection procedure for yield improvement in wheat. Accordingly, Casali and Tigchelaar (1975) compared PS, SSD and bulk breeding methods in self-pollinated populations by computer simulation.

\section{REFERENCES}

Allard, R.W. and J. Adams (1969). Population studies in predominantly selfpollinated species XIII-Inter genotypic competition and population structure in barley and wheat. Amer. Natural 103; 6211-6245

Atkins, R. E. (1953). Effect of selection upon bulk hybrid barley populations. Agron. J., 45: 311-314.

Arunachalam A.; K.P. Viswantha; K.K. Chakravarthy; A. Manjunathe and M.K. Jayashree (2002). Efficiency of breeding methods in early segregating generations in cowpea (Vigna unguiculata L.) Walp. Ind. J.Genet., 62(3): 228-231. 
Casali, V.W.D. and E.C. Tigchelaar (1975). Computer simulation studies comparing pedigree, bulk and single seed descent selection in self pollinated populations. J. Am. Soc. Hort. Sci. 100: 364- 367.

El-Shamy, M. (1987). Studies on wheat breeding. Alex. J. Agric. Res., 32: (3), 495-505.

Ismail, A. A. (1995). Pedigree selection for grain yield, grain weight and earliness in two segregating populations of spring wheat. (BIBLIOGRAPHIC CITATION): Assiut J. Agric. Sci., 26: (4), 59-72.

Knott, D. R. and J. Kumar (1975). Comparison of early generation yield testing and a single seed descent procedure in wheat breeding. Crop Sci., 15: 295-299.

Malysh L.K and N.D. Fomenko (1988). Comparison of a modified pedigree method (single seed descent) and mass selection in breeding soyabean .Rezervy-povysheniya-effektivnosti-soevodstva. 2-18

Pawar, I. S. ; R. S. Paroda and S. Singh, (1986). A comparison of pedigree selection, single seed descent and bulk methods in two wheat (Triticum aestivum L. em Thell.) crosses. Crop-Improvement., 13 (1): 34-37.

Pawar, I. S. ; R. S. Paroda; M. Yunus and S. Singh (1985). A comparison of three selection methods in two wheat crosses. C. F. Plant Breeding Abst., 57 (8): 4617.

Pawar, I. S. ; R. S. Paroda and S. Singh (1989). Study of heritability and genetic advance in three wheat populations. (BIBLIOGRAPHIC CITATION): Bangladesh- Journal- of- Agricultural- Research., 14 (1): 24-26.

Pawar, I. S. ; A. S. Redhu; S. Iqbal and M. Yunus (2001). Effectiveness of selection procedures in wheat. (BIBLIOGRAPHIC CITATION): Haryana- Agric. Univ. J.- of- Res., 31: (3-4): 119-121.

Ronga, G. ; M.D Ninno-; N.D Fonzo-; M. De-Ninno and N. Di-Fonzo (1995). Combining ability as a criterion for the choice of parents for pedigree selection programs in durum wheat. (BIBLIOGRAPHIC CITATION): Agricoltura- Mediterranea., 125(4): 387-394.

Salmeron, J. J. (1985). Response of grain yield, plant height and kernel weight in three winter wheat crosses (Triticum aestivum, L. em. Thell.) to different methods of selection. Dissertation-Abstracts-International,B-Sciences-and-Engineering., 46 (5): 1395 B.

Schutz, W.M.; C.A. Brim and S.A. Usnasis (1968). International competition in plant population. 1- Feed back system with stable equalibiria in population of autogamous homozygous lines. Crop Sci. 8: 61-66.

Snape, J. W. ; J. W. Ouyang; B. B. Parker and S. E. Jia (1992). Evidence for genotypic selection in wheat during the development of recombinant inbred lines by anther culture and single seed descent. (BIBLIOGRAPHIC CITATION): J.- of- Genetic- and- Breeding., 46(2): 167-172.

Srivastava, R. B. ; R. S. Paroda; S. C. Sharma and M. D. Yunus (1989). Genetic variability and advance under four selection procedures in wheat pedigree breeding program. (BIBLIOGRAPHIC CITATION): Theoretical- and- Applied- Genetics., 77(4): 516-520.

Verma, S. R. ; M. Yunus ; S. K. Sethi; H. J. Braun; F. Altay ; W. E. Kronstad; S. P.S. Beniwal and A. McNab (1997). Breeding for yield and quality in durum wheat. (BIBLIOGRAPHIC CITATION): Developmentsin- Plant- Breeding., 6: 61-64. 


\section{El-Hosary, A. A. et al.}

Whan B.R.; R. Knight and A.J. Rathjen (1982). Response to selection for grain yield and harvest index in $\mathrm{F}_{2}, \mathrm{~F}_{3}$ and $\mathrm{F}_{4}$ derived lines of two wheat crosses. Euphytica, 31: 139-150.

كفاءة ثلاثة طرق تربية علي هجينين من قمح الخبز

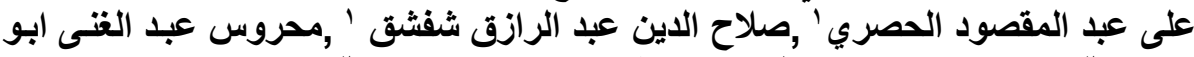

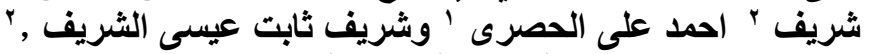

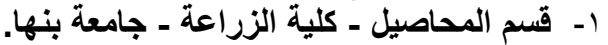

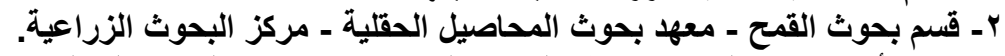

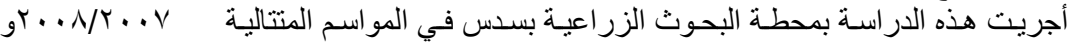

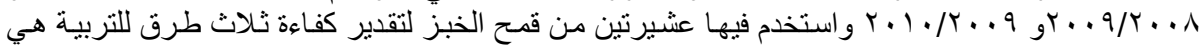

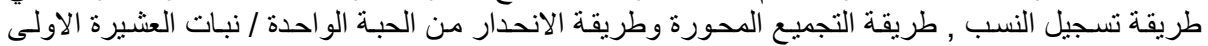

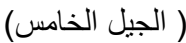

أنثارت المتوسطات الى أن هناك معنوية لكل طرق التربية بالنسبة لصفات المحصول ومكوناته و النتائج توضح الفروق بين طرق التربية المختلفة.

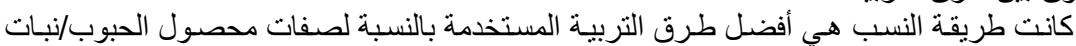

ووزن ال .. احبة و عدد الحبوب/السنبلة وعدد السنابل/النبات مقارنة بطريقة التجميع وطريقة الحبة الواحدة

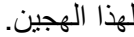

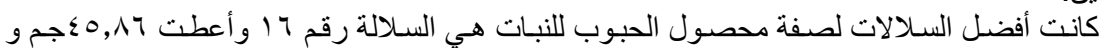

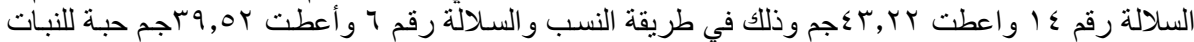

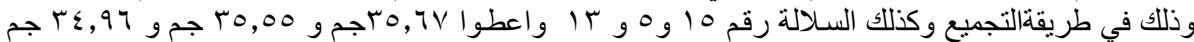

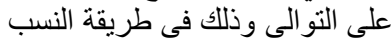

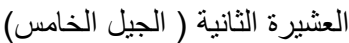

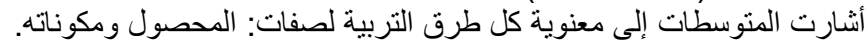

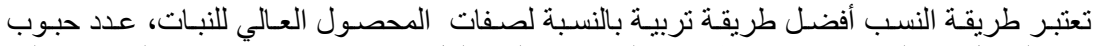
السنبلة و عدد السنابل فى النباتات مقارنة بطريقتي التجميع و الحبه لكل نبات نبات ينما اعطت طريقة التجميع اعلى لئى

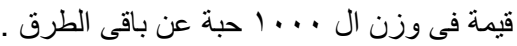

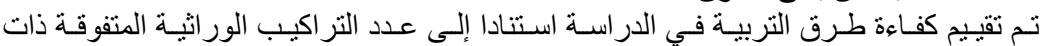

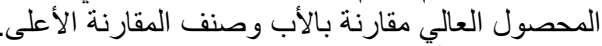

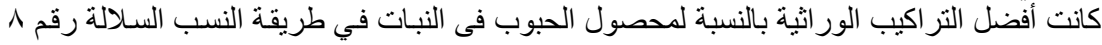

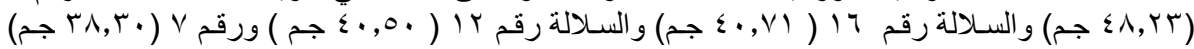

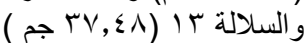

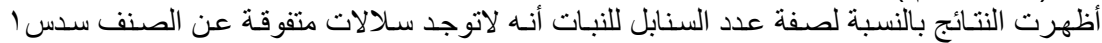
معنويا ولكن طريقة تسجيل النسب نتج عنها أفضل السلالات يليها طريقة التجميع ثم طريقة الانحدار عن الندان

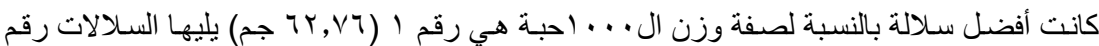

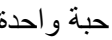

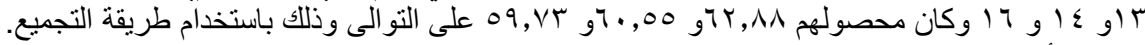

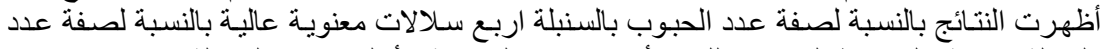

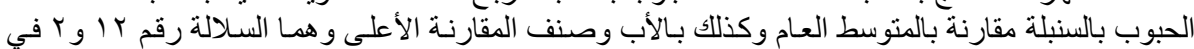

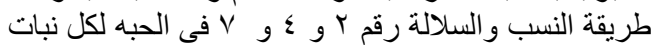

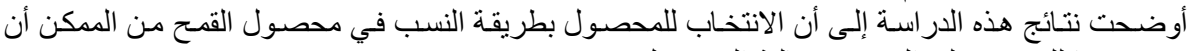
يقودنا للتعرف على السلالات عالية المحصول.

كلية الزراعة - جامعة المنصورة كلية الزراعة بثبين الكوم - جامعة المنوفية
قام بتحكيم البحث

أ.د / محمود سليمان سلطان أ.د / حسان عبد الحميد دوام 